\title{
O KONIECZNOŚCI POLSKIEGO PRZEKŁADU PIERWSZEGO WYDANIA BAŚNI DLA DZIECI I DLA DOMU BRACI GRIMM Z LAT 1812 I 1815
}

DOl: http://dx.doi.org/10.12775/RP.2016.004

Zarys treści: Baśnie braci Grimm należą do kanonu literatury światowej, a zainteresowanie nimi nie słabnie. Czytelnik (naukowiec) polski zwykle obcuje z baśniami Grimmów za sprawą przekładu, więc recepcja baśni w Polsce zależy od wierności danego łłumaczenia. Równocześnie wszystkie istniejące polskie przekłady baśni braci Grimm opierają się na ich ostatnim, siódmym wydaniu, pochodzącym z roku 1857, które znacznie różni się od wydania pierwszego z lat 1812 (t. 1) i 1815 (t. 2). W niniejszym tekście ukazane zostaną powody uzasadniające konieczność przekładu pierwszego wydania baśni oraz zaprezentowane będą wstępne wnioski wynikające z analizy językowej i treściowej wykonanych przeze mnie tłumaczeń baśni pochodzących z pierwszego wydania.

Słowa kluczowe: baśnie braci Grimm, przekład baśni

Raśnie zebrane przez braci Jakuba i Wilhelma Grimmów należą do kanonu Dliteratury światowej, a zainteresowanie nimi nie słabnie - zarówno w odbiorze masowym, jak i w ramach badań naukowych.

Równocześnie merytoryczny namysł nad baśniami Grimmów - zarówno popularnonaukowy, jak i stricte naukowy - nie jest możliwy bez znajomości szczególnych cech tego zbioru. Nie można formułować wiążących opinii, nie znając źródeł i genezy zbioru czy nie mając świadomości, że baśnie podlegały wielokrotnym i wieloletnim pracom redakcyjnym.

Dla polskiego odbiorcy (badacza), który nie zna języka oryginału, sprawa komplikuje się dodatkowo, ponieważ obcuje on z baśniami Grimmów 
za pośrednictwem przekładu, który nie jest neutralnym medium: odbiorca przekładu staje się bowiem zakładnikiem założeń wstępnych tłumaczy. To od rozstrzygnięć tłumaczy zależeć będzie, z jakim tekstem obcować będzie czytelnik. Zatem recepcja baśni w Polsce w dużej części uzależniona jest od stopnia wierności danego przekładu wobec oryginału (przy czym od razu zaznaczyć trzeba, że w przypadku baśni braci Grimm, zaliczanych obecnie do tzw. literatury dziecięcej, ów stopień wierności jest stosunkowo niski: z badań w ramach nurtu children's literature translation studies jasno wynika, że w przekładach literatury dziecięcej to właśnie adaptacja jest normą, a wierny przekład wyjątkiem).

Równocześnie łatwo zagubić się w gąszczu przekładów, starych i nowych, wiernych, wolnych i zupełnie dowolnych, które tak naprawdę trudno jest zliczyć. Heroicznej próby „rekonesansu bibliograficznego” polskich przekładów baśni braci Grimm w latach 1895-2011 podjęła się Bogumiła Staniów (2014). Spis przekładów, które ukazały się po roku 1989, zajmuje aż trzy strony¹.

Można wybaczyć laikowi, że nie zwraca uwagi na to, w jakim przekładzie (czy adaptacji) czyta daną baśń, oraz że nie jest świadomy, iż przekład to nie oryginał, lecz wersja będąca wynikiem wielu wstępnych założeń tłumacza, jego sprawności językowej oraz decyzji wydawniczych².

W tym miejscu jednak chciałabym zwrócić uwagę na fakt, że często sami naukowcy zajmujący się w swej pracy baśniami Grimmów, niebędący germanistami i przez to niemający dostępu do tekstu oryginalnego, zapominają, że obcują z przekładami, i często na podstawie swobodnych lub przypadkowo dobranych ${ }^{3}$ przekładów formułują wnioski, które nie mają wiele wspólnego z treścią czy przesłaniem oryginału. Dla zilustrowania tego zjawiska podam tylko dwa spośród bardzo wielu przykładów.

I tak, nie można badać „językowego obrazu rodziny w baśniach braci Grimm" (Kondratczyk 2013) i formułować wiążących wniosków na podstawie częstotliwości użycia słów „ojciec”, „córka”, „syn”, jeśli autorka opiera się na jednym przekładzie, a do tego nie sprawdza, z jakimi niemieckimi odpo-

1 Staniów zestawia przekłady baśni, czyli takie wydania, które są uznawane za przekład z języka oryginału i wymieniają z nazwiska tłumacza. Tymczasem baśnie Grimmów wydawane są w języku polskim także jako adaptacje - często bardzo swobodne.

2 Szczególnie w przypadku tłumaczeń dla dzieci to wydawnictwo, a nie tłumacz, ma decydujący głos w sprawie edycji tłumaczonego tekstu. Dochodzą do tego także obiektywne czynniki, takie jak obecność ilustracji czy przystosowanie tekstu do głośnej lektury.

3 Przypadkowy dobór przekładów to dość nagminna praktyka: badacze często nie zdają sobie sprawy, że sięgają po przekłady, które wydawnictwa dostosowały do wymogów odbiorcy dziecięcego, i traktują je jak tożsame z oryginałem. 
wiednikami korespondują w danych cytatach polskie słowa. Pomijam już najistotniejszą chyba sprawę, czy owe odpowiedniki („Vater”, „Tochter”, „Sohn”) przekazują ten sam językowy obraz świata. W tym kontekście anegdotyczne wręcz są rozbudowane analizy polskojęzycznej formy „Córuchno!”, jeśli język niemiecki nie ma wołacza ani analogicznej formy o podobnym zabarwieniu emocjonalnym. Omawiany artykuł powinien więc nosić tytuł: „Językowy obraz rodziny w polskim przekładzie baśni braci Grimm autorstwa M. Tarnowskiego i E. Bielickiej, na podstawie wydania Baśnie dla najmłodszych z roku 1993".

I podobnie, nie można analizować „motywu wędrówki na przykładzie wybranych baśni braci Grimm” (por. Krawczyk 2013), odwołując się do jednego, na dodatek bardzo swobodnego przekładu Cecylii Niewiadomskiej, a swoje wnioski dotyczące motywu wędrówki opierać na fragmentach tekstów, których nie ma w oryginalnych baśniach, gdyż akurat te fragmenty tłumaczka dopisała sama. Autorka artykułu przeanalizowała zatem motyw wędrówki w przekładach Cecylii Niewiadomskiej, a jej wnioski siłą rzeczy dotyczą pomysłów translatorskich Niewiadomskiej, a nie oryginalnych baśni Grimmów.

Jak widać, nawet $\mathrm{w}$ opracowaniach naukowych brakuje wiedzy na temat tego, czym jest, a czym nie jest przekład. A jeśli dodać do tego złożone dzieje oryginalnych baśni, widać, że mamy do czynienia z dość skomplikowaną materią. $\mathrm{Z}$ tego względu, zanim przejdę do głównego problemu, czyli prezentacji argumentów na rzecz polskiego przekładu pierwszego wydania baśni z lat 1812 i 1815, chciałabym poczynić kilka uwag wstępnych dotyczących oryginalnego zbioru.

\section{Czym jest zbiór Kinder- und Hausmärchen?}

Wokół baśni Grimmów narosło - przede wszystkim za sprawą samych autorów - wiele mitów. Dwa najbardziej rozpowszechnione to uznanie, że 1) baśnie „zebrane przez braci Grimm” (jak głosi podtytuł) są „,wiernym zapisem ustnej tradycji ludowej" oraz 2) że Jakub i Wilhelm Grimm osobiście wędrowali po niemieckich wsiach w poszukiwaniu tych baśni. Sami Grimmowie w przedmowach do kolejnych wydań podkreślali, iż starają się utrwalić na piśmie to, „co wśród ludu przetrwało”.

Świadomie, lecz niekoniecznie w złych zamiarach, Grimmowie pomijają źródła swych baśni, a zatem zamiast podawać nazwisko danego informato- 
ra, dołączają jedynie informację o geograficznym pochodzeniu opowieści: „Z Hesji”, „Z Bawarii” (por. Martus 2013: 209), a służąc idei poszukiwania mitycznego „ducha ludu” (Volksgeist), swój zbiór prezentują jako „zbiór ustnych, w większości przez nas samych zapisanych przekazów" (por. Martus 2013: 208). W ostatnich latach w Niemczech, szczególnie w związku z rokiem jubileuszowym, pojawiło się wiele demitologizujących publikacji ukazujących złożone źródła baśni Grimmów. Stąd wiadomo, że bracia nie czerpali tylko z tradycji ustnej, lecz również jak najbardziej z tekstów pisanych (dawnych antologii, dzieł literackich, autentycznych kazań średniowiecznych itp.).

Sprawy komplikują się także w wypadku kluczowego zagadnienia - tradycji ludowej, bo informatorami braci w większości nie byli anonimowi prości ludzie ze wsi, lecz dobrzy znajomi z najbliższego kręgu przyjaciół ${ }^{4}$ i nawet legendarna „chłopka” ze wsi Niederzwehrn, Dorothea Viehmann, okazała się wykształconą kobietą o hugenockich korzeniach (por. Martus 2013: 210). W tym kontekście warto też wspomnieć o wpływie tradycji francuskich, których tak bardzo wystrzegali się Grimmowie 5 .

$\mathrm{Na}$ te dość skomplikowane dzieje powstania zbioru nakładają się dalsze losy baśni, ponieważ pierwsze wydanie baśni z roku $1812^{6}$ rozpoczyna długą serię kolejnych edycji (w sumie siedmiu, jeśli liczyć tylko tzw. wielkie wydanie) i zabiegów redakcyjnych, które kończą się dopiero wraz z siódmym wydaniem w roku 1857, ostatnim autoryzowanym przez obojga braci (Ausgabe letzter Hand). Można założyć, że gdyby Wilhelm Grimm pożył dłużej (a zmarł w roku 1859, w dwa lata po siódmym wydaniu baśni), prawdopodobnie pojawiłyby się kolejne edycje i kolejne zmiany redakcyjne, dlatego że Wilhelm przez czterdzieści pięć lat, jakie dzieliły pierwsze wydanie od ostatniego, nieustannie poprawiał i ulepszał te teksty. Kierował się przy tym określonymi założeniami. Omówię je bardziej szczegółowo, bo równocześnie ukazują one swoistość pierwszej wersji baśni braci Grimm z lat 1812 i 1815, której przekład na język polski postuluję.

${ }^{4}$ Co wiernie rekonstruuje Heinz Rölleke w książce Die wahren Märchen der Brüder Grimm und wer sie ihnen erzählte (2011).

${ }^{5}$ Baśnie powstawały w czasach wojen napoleońskich, więc nastroje antyfrancuskie były zrozumiałe w podbitej przez Francuzów Hesji. Ponadto Grimmowie pragnęli odnaleźć ducha niemieckiej poezji ludowej, więc nie po drodze było im z jakimikolwiek obcymi wpływami. Z tego względu wycofali z kolejnych wydań Kota $w$ butach jako nazbyt francuskiego oraz zastępowali wyrazy pochodzenia francuskiego (jak np. „Fee” - 'wróżka') rodzimym odpowiednikiem „die weise Frau” - 'mądra niewiasta'.

${ }^{6}$ W roku 1812 ukazał się tom pierwszy, zawierający 86 baśni, a w roku 1815 - tom drugi, z kolejnymi 70 baśniami. 


\section{Cechy szczególne pierwszego wydania}

Problematyka zmian redakcyjnych, którym przez 45 lat podlegały teksty baśni, jest o tyle istotna dla polskiego badacza, że wszystkie przekłady dokonane na język polski, opierają się na ostatnim wydaniu baśni z roku 1857, czyli wersji per definitionem najbardziej zmienionej w stosunku do wydania pierwszego. Ten jakże istotny fakt zwykle nie był jak dotąd przedmiotem głębszego namysłu wśród polskich badaczy, a przecież zmiany, jakie wprowadził Wilhelm Grimm, są natury zasadniczej.

Chciałabym tutaj sformułować wstępną tezę, że wydanie z roku 1812 i wydanie $z$ roku 1857 to dwa zupełnie różne zbiory baśni - oparte na różnych założeniach wstępnych i kierowane do odmiennych grup odbiorców. Już sam ten fakt wskazuje jasno, że znając wyłącznie jedną ich wersję z roku 1857, nie mamy pełnej wiedzy na temat całościowego zjawiska, jakim są baśnie braci Grimm, a wszelkie wnioski formułowane na podstawie istniejących przekładów na język polski automatycznie ograniczają się wyłącznie do ostatniego wydania.

Zamysłem pierwszego wydania baśni, mimo że było ono od początku zatytułowane Kinder- und Hausmärchen (w skrócie: KHM), a zatem za sprawą członu „Kinder” sugerowało odbiorcę dziecięcego, było dokumentarne i skrupulatne zapisanie otrzymanych opowieści. Projektowanym odbiorcą tego zbioru miał być dorosły i to dorosły zainteresowany nie tyle przyjemną lekturą starych baśni, co raczej ich aspektami filologicznymi, historycznymi i folklorystycznymi - mówiąc innymi słowy, bracia Grimm w roku 1812 kierowali swój zbiór do sobie podobnych pasjonatów i naukowców. Prawdopodobnie optymalnymi odbiorcami zbioru KHM z roku 1812 byli sami autorzy, Jakub i Wilhelm Grimm.

Gdy pierwsze wydanie baśni pojawiło się na rynku krótko przed Bożym Narodzeniem, a więc trafiło $\mathrm{w}$ wielu domach pod choinkę, do braci dotarły alarmujące wieści, że baśnie zupełnie nie nadają się do czytania dzieciom (por. Ewers 2012: 41). Począwszy od drugiego wydania (1819), Wilhelm Grimm rozpoczyna swoją wielką pracę redakcyjną i stopniowo przekształca baśnie, przeznaczone pierwotnie dla dorosłych, w czystą literaturę dziecięcą (por. Martus 2013: 211 i n.). To jest właśnie powód, dla którego pierwsze wydanie z roku 1812 stanowi zupełnie inną jakość w stosunku do kolejnych sześciu wydań - coraz bardziej modyfikowanych, cenzurowanych i wygładzanych.

Opowieści ludowe w swym autentycznym kształcie były bowiem dla kultury literackiej XIX i XX wieku - jak pisze Hans-Heino Ewers (2012: 39) całkowicie „niestrawne - zbyt płaskie, zbyt wulgarne, zbyt ordynarne, zbyt 
drastyczne..."”. Dopiero teraz zaczynamy doceniać ich pierwotny urok i autentyczność.

\subsection{Styl pierwszego wydania}

Lektura pierwszego wydania baśni ujawnia to w całej rozciągłości: baśnie są krótkie, zapisane stylem naśladującym język mówiony, jakby celowo niedbałym. Teksty te wyróżnia duża liczba elips. Nie ma tu prawie zdań podrzędnie złożonych, a zdania współrzędnie złożone, oddzielone od siebie przecinkami, ciągną się przez całe akapity. Partie dialogowe wplecione są w tekst i czasem oddzielone jedynie przecinkami od narracji. Wszystko razem tworzy wrażenie naturalnej, potoczystej wypowiedzi ustnej, a porównanie z późniejszymi edycjami, jasno ukazuje, że w pierwszym wydaniu bracia świadomie powstrzymali się przed wygładzaniem tekstu.

Warto zilustrować to przykładem pochodzącym z pierwszej baśni zbioru, czyli fragmentem Żabiego króla. Poniższy cytat jest bardzo charakterystyczny: mamy tutaj do czynienia $\mathrm{z}$ długim ciągiem zdań oddzielonych od siebie przecinkami i nie zawsze połączonych spójnikami. Dodatkowo odnajdziemy tu mowę zależną, która w zaskakujący sposób przechodzi w mowę niezależną - jak w opowieści ustnej, w której narrator płynnie zmienia perspektywę opowiadania i przechodzi od narracji do wypowiedzi bohaterów:

Die Königstochter dachte, was schwätzt der einfältige Frosch wohl, der muß doch in seinem Wasser bleiben, vielleicht aber kann er mir meine Kugel holen, da will ich nur ja sagen; und sagte: „ja meinetwegen, schaff mir nur erst die goldne Kugel wieder, es soll dir alles versprochen seyn." (Grimm 1812:2)

Królewna pomyślała, co ta głupia żaba najlepszego wygaduje, przecież musi zostać w wodzie, ale chyba może mi przynieść moją kulę, więc wystarczy, że się zgodzę; i powiedziała: „Tak, oczywiście. Tylko najpierw przynieś mi złotą kulę, wszystko będzie ci obiecane"s.

Dla porównania ten sam fragment został w wydaniu z roku 1857 zmieniony wręcz nie do poznania, jakby sam Wilhelm Grimm uznał, że w takim

${ }^{7}$ Równocześnie warto podkreślić, że redakcyjne zmiany w baśniach wydatnie przyczyniły się do późniejszego wielkiego sukcesu zbioru, podczas gdy wydanie pierwsze i drugie przeszły praktycznie bez echa.

${ }^{8}$ Robocze tłumaczenia baśni braci Grimm z roku 1812 wykonane zostały przez autorkę niniejszego artykułu. 
kształcie jak z roku 1812 tekst nie może się znaleźć w poważnej książce dla dzieci.

„Ach ja, "sagte sie, „ich verspreche dir alles, was du willst, wenn du mir nur die Kugel wieder bringst. "Sie dachte aber „was der einfältige Frosch schwätzt, der sitzt im Wasser bei seines Gleichen und quackt, und kann keines Menschen Geselle sein."(Grimm 1857:2) - Ależ tak! - powiedziała. - Obiecam ci wszystko, co chcesz, tylko przynieś mi moja kulę.

W duszy jednak pomyślała: „Co też ta głupia żaba wygaduje? Niech siedzi w wodzie $z$ podobnymi sobie i rechocze. Przecież żaba nie może być kompanem człowieka". (Grimm 2010: t. 1: 12)

Jeśli porównamy te dwa fragmenty, zauważymy, że zmieniona została kolejność: w nowszej edycji najpierw mamy wypowiedź królewny skierowaną do żaby, a dopiero potem - by wprowadzić element zaskoczenia - czytelnik dowiaduje się prawdziwych myśli królewny. Ponadto jej monolog wewnętrzny zostaje uzupełniony o wyjaśnienie (prawdopodobnie ze względu na odbiorcę dziecięcego), że „przecież żaba nie może być kompanem człowieka”. Wersja z roku 1857 jest z pewnością bardziej poprawna stylistycznie, przejrzysta i logiczna, ale w wyniku tych zmian ginie bezpowrotnie szczególna bezpretensjonalność i naturalność pierwotnego tekstu.

\subsection{Zmiany treściowe wobec pierwszego wydania}

Poza wspomnianymi powyżej przeróbkami stylistycznymi najwięcej zmian należy odnotować na płaszczyźnie treściowej, aż po zmiany najbardziej radykalne, czyli całkowitą rezygnację z 37 tekstów, które zostały wycofane z kolejnych wydań.

\subsubsection{Lista wycofanych baśni}

W poniższej tabeli znajduje się lista 37 baśni, które nie trafiły do kolejnych wydań. Większość z nich, bo aż 33 zostały wycofane już przy okazji drugiego wydania z roku 1819. Cztery baśnie (nr 43, 104, 107 i 136) przetrwały trochę dłużej, ale w wersji z roku 1857 już się nie pojawiły. Jedna z baśni (nr 121) trafiła potem do części zbioru zawierającego legendy dziecięce (Kinderlegenden). W tabeli znajdują się także tytuły baśni (wraz z ich polską wersją), którymi zastąpiono wycofane teksty. 


\begin{tabular}{|c|c|c|}
\hline nr & wydanie 1812 & $\begin{array}{c}\text { wydanie } 1857 \text { / tytuł polski jak } \\
\text { w wydaniu z } 2010\end{array}$ \\
\hline 6 & Von der Nachtigal und der Blindschleiche & Der treue Johannes / Wierny Jan \\
\hline 8 & Die Hand mit dem Messer & $\begin{array}{l}\text { Der wunderliche Spielmann / Grajek } \\
\text { cudak }\end{array}$ \\
\hline 16 & Herr Fix und Fertig & $\begin{array}{l}\text { Die drei Schlangenblätter / Trzy wężowe } \\
\text { listki }\end{array}$ \\
\hline 22 & $\begin{array}{l}\text { Wie Kinder Schlachtens miteinander } \\
\text { gespielt haben }\end{array}$ & Das Rätsel / Zagadka \\
\hline 27 & Der Tod und der Gänsehirt & $\begin{array}{l}\text { Die Bremer Stadtmusikanten / Miejscy } \\
\text { muzykanci z Bremy }\end{array}$ \\
\hline 33 & Der gestiefelte Kater & Die drei Sprachen / Trzy języki \\
\hline 34 & Hansens Trine & Die kluge Else / Mądra Elżunia \\
\hline 37 & $\begin{array}{l}\text { Von der Serviette, dem Tornister, dem } \\
\text { Kanonenhütlein und dem Horn }\end{array}$ & Daumesdick / Paluszek \\
\hline 43 & $\begin{array}{l}\text { Die wunderliche Gasterei (baśń obecna } \\
\text { w I i II wydaniu) }\end{array}$ & Frau Trude / Pani Trude \\
\hline 54 & Hans Dumm & $\begin{array}{l}\text { Der Ranzen, das Hütlein und das Hörn- } \\
\text { lein / Tornister, czapeczka i róg }\end{array}$ \\
\hline 59 & Prinz Schwan & $\begin{array}{l}\text { Der Frieder und das Katherlieschen / Fryc } \\
\text { i Katarzynka }\end{array}$ \\
\hline 60 & Das Goldei & Die zwei Brüder / Dwaj bracia \\
\hline 61 & Von dem Schneider, der bald reich wurde & Das Bürle / Chłopek \\
\hline 62 & Der Blaubart & Die Bienenkönigin / Królowa pszczół \\
\hline 64 & Von dem Dummling & Die goldene Gans / Złota gęś \\
\hline 66 & Hurleburlebutz & Häsichenbraut / Narzeczona zajączka \\
\hline 68 & Von dem Sommer- und Wintergarten & $\begin{array}{l}\text { De Gaudeif un sien Meester / Kuglarz } \\
\text { i jego mistrz }\end{array}$ \\
\hline 70 & Der Okerlo & $\begin{array}{l}\text { Die drei Glückskinder / Trzech szczęśliw- } \\
\text { ców }\end{array}$ \\
\hline 71 & Prinzessin Mäusehaut & $\begin{array}{l}\text { Sechse kommen durch die ganze Welt / } \\
\text { Sześciu zdobędzie cały świat }\end{array}$ \\
\hline 72 & Das Birnli will nit fallen & $\begin{array}{l}\text { Der Wolf und der Mensch / Wilk } \\
\text { i człowiek }\end{array}$ \\
\hline 73 & Das Mordschloß & Der Wolf und der Fuchs / Wilk i lis \\
\hline 74 & $\begin{array}{l}\text { Von Johannes-Wassersprung und Caspar- } \\
\text { Wassersprung }\end{array}$ & $\begin{array}{l}\text { Der Fuchs und die Frau Gevatterin / Lis } \\
\text { i pani kuma }\end{array}$ \\
\hline 75 & Vogel Phönix & Der Fuchs und die Katze / Lis i kot \\
\hline 77 & Vom Schreiner und Drechsler & Das kluge Gretel / Mądra Małgorzatka \\
\hline 81 & Der Schmidt und der Teufel & Bruder Lustig / Brat łata \\
\hline 84 & Die Schwiegermutter & Hans heiratet / Jaś się żeni \\
\hline
\end{tabular}




\begin{tabular}{|c|c|c|}
\hline 85 & Fragmente & Die Goldkinder / Złote dzieci \\
\hline 99 & Der Froschprinz & Der Geist im Glas / Duch w butelce \\
\hline 104 & $\begin{array}{l}\text { Die treuen Tiere (baśń obecna w wyda- } \\
\text { niach od I do VI) }\end{array}$ & Die klugen Leute / Mądrzy ludzie \\
\hline 107 & $\begin{array}{l}\text { Die Krähen (baśń obecna w wydaniach } \\
\text { od I do IV) }\end{array}$ & Die beiden Wanderer / Dwaj wędrowcy \\
\hline 119 & Der Faule und der Fleißige & Die sieben Schwaben / Siedmiu Szwabów \\
\hline 121 & $\begin{array}{l}\text { Die himmlische Hochzeit (potem Kinder- } \\
\text { legende 9) }\end{array}$ & $\begin{array}{l}\text { Der Königssohn, der sich vor nichts fürch- } \\
\text { tet / Królewicz, który niczego się nie lęka }\end{array}$ \\
\hline 129 & Der Löwe und der Frosch & $\begin{array}{l}\text { Die vier kunstreichen Brüder / Czterech } \\
\text { zmyślnych braci }\end{array}$ \\
\hline 130 & Der Soldat und der Schreiner & $\begin{array}{l}\text { Einäuglein, Zweiäuglein und Dreiäuglein / } \\
\text { Jednooczka, Dwuoczka, Trójoczka }\end{array}$ \\
\hline 136 & $\begin{array}{l}\text { De wilde Mann (baśń obecna w wyda- } \\
\text { niach od I do V) }\end{array}$ & Der Eisenhans / Żelazny Jan \\
\hline 143 & Die Kinder in Hungersnoth & Up Reisen gohn / O podróżowaniu \\
\hline 152 & Die heilige Frau Kummerni $\beta$ & Das Hirtenbüblein / Pastuszek \\
\hline
\end{tabular}

Wobec tak obszernej listy wycofanych i praktycznie nieznanych w Polsce baśni (oczywiście poza Kotem $w$ butach i Sinobrodym) najważniejsze wydaje się pytanie o przyczynę, dla której autorzy postanowili zrezygnować z tych kilkudziesięciu tekstów. Wstępnie można wyróżnić następujące powody:

1) wycofanie baśni z powodu ich jawnie francuskiego pochodzenia (dotyczy to Kota w butach i Sinobrodego),

2) wykorzystanie motywu $z$ danej baśni do rozbudowania innej fabuły (Fragmente),

3) rezygnacja $\mathrm{z}$ baśni z powodu powtarzalności motywu w innym tekście (Froschprinz),

4) rezygnacja z baśni z powodu jej drastyczności (Die Hand mit dem Messer),

5) zastąpienie baśni zupełnie inną, z różnych powodów uznaną przez autorów za bardziej cenną.

Można by mniemać, że większość baśni została wycofana z powodu ich drastyczności, jednak to właśnie powód ostatni (zastąpienie jednej fabuły przez zupełnie odmienną) wydaje się najczęstszy, bo w wielu przypadkach trudno doszukać się innych przyczyn, dla których autorzy musieliby zrezygnować z całkiem udanych fabuł, jak na przykład z nieznanej w Polsce sowizdrzalskiej opowieści Herr Fix und Fertig (tytuł roboczy Pan Szast Prast). 
Warto też zauważyć, że wśród baśni, które zastąpiły wycofane teksty, znajduje się kilka bardzo znanych (np. Die Bremer Stadtmusikanten czy Daumesdick), co także nieco rozjaśnia problem.

W niewielu przypadkach sprawa jest tak ewidentna jak w odniesieniu do baśni Wie Kinder Schlachtens miteinander gespielt haben. Tutaj autorzy zostali wręcz zobligowani do wycofania baśni jako nieodpowiedniej dla dzieci, chociaż osobiście byli bardzo do niej przywiązani i uważali ją za pouczającą i potrzebną właśnie dzieciom. Warto przyjrzeć się jej w całości, by samemu wyrobić sobie pogląd. Baśń ta, pod roboczym tytułem Jak dzieci bawity się ze sobą $w$ bicie świni, prezentuje się następująco:

Einstmals hat ein Hausvater ein Schwein geschlachtet, das haben seine Kinder gesehen; als sie nun Nachmittag mit einander spielen wollen, hat das eine Kind zum andern gesagt: „du sollst das Schweinchen und ich der Metzger seyn;“ hat darauf ein bloß Messer genommen, und es seinem Brüderchen in den Hals gestoßen. Die Mutter, welche oben in der Stube saß und ihr jüngstes Kindlein in einem Zuber badete, hörte das Schreien ihres anderen Kindes, lief alsbald hinunter, und als sie sah, was vorgegangen, zog sie das Messer dem Kind aus dem Hals und stieß es im Zorn, dem andern Kind, welches der Metzger gewesen, ins Herz. Darauf lief sie alsbald nach der Stube und wollte sehen, was ihr Kind in dem Badezuber mache, aber es war unterdessen in dem Bad ertrunken; deßwegen dann die Frau so voller Angst ward, daß sie in Verzweifelung gerieth, sich von ihrem Gesinde nicht wollte trösten lassen, sondern sich selbst erhängte. Der Mann kam vom Felde und als er dies alles gesehen, hat er sich so betrübt, daß er kurz darauf gestorben ist. (Grimm 1812: 103) Pewnego razu ojciec rodziny zarzynał świnię, a jego dzieci się temu przyglądały; a gdy po południu zaczęły się ze sobą bawić, jedno dziecko powiedziało do drugiego:

- Ty będziesz świnką, a ja rzeźnikiem.

Po tych słowach wzięło nóż i wbiło go w szyję swojego braciszka. Matka, która siedziała na górze w izbie i kąpała w cebrzyku swoje najmłodsze dziecko, usłyszała krzyk drugiego dziecka. Natychmiast zbiegła na dół, a gdy zobaczyła, co się stało, wyciągnęła nóż z szyi dziecka i w gniewie wbiła go w serce drugiego dziecka, które było rzeźnikiem. Potem szybko pobiegła z powrotem do izby, żeby zobaczyć, co robi jej dziecko w cebrzyku, ale ono już utopiło się w kąpieli. I kobieta tak bardzo się przeraziła, że wpadła w rozpacz i nie przyjęła pocieszeń swojej służby, lecz się powiesiła. Mąż wrócił z pola, a gdy wszystko to zobaczył, tak się zasmucił, że krótko potem umarł. 


\subsubsection{Zmiany treściowe}

Większość ze 156 baśni pierwszego wydania pozostała w zbiorze, jednak w ramach pracy redakcyjnej Wilhelm Grimm nie tylko szlifował styl baśni, lecz również dokonywał zmian w ich treści. Badacze wskazują, że kierował się przy tym dwoma podstawowymi założeniami: po pierwsze, cenzurował aluzje erotyczne, a po drugie, starał się łagodzić pogański wydźwięk tekstu, odwołując się do wartości chrześcijańskich (pokory, poświęcenia, miłości bliźniego) i nadając bohaterom pobożne cechy.

Poza szeroko znanym faktem ocenzurowania Roszpunki ingerencje Wilhelma odnaleźć można w wielu innych miejscach. Tutaj ponownie odwołam się do pierwszej baśni ze zbioru, by pokazać, w jaki sposób łagodzono dwuznaczności. I tak, w pierwszym wydaniu czytamy:

Aber der Frosch fiel nicht todt herunter, sondern wie er herab auf das Bett kam, da wars ein schöner junger Prinz. Der war nun ihr lieber Geselle, und sie hielt ihn werth wie sie versprochen hatte, und sie schliefen vergnügt zusammen ein. Am Morgen aber kam ein prächtiger Wagen... (Grimm 1812: 4 i n.)

Ale żaba nie upadła martwa na ziemię, lecz gdy weszła na łóżko, był to piękny młody książę. I teraz był jej kochanym towarzyszem, a ona była mu przychylna, jak [wcześniej] obiecała, i zasnęli razem zadowoleni. Rano nadjechała wspaniała kareta...

Ostatnie zdanie powyższego cytatu nie pozostawia wątpliwości co do jego erotycznego wydźwięku: książę staje się niniejszym ,jej kochanym towarzyszem", królewna - zgodnie z obietnica - okazuje mu przychylność, a na koniec młodzi ludzie zasypiają razem „zadowoleni”.

Gdy czyta się wersję z roku 1857, można sobie bez trudu wyobrazić męki Wilhelma Grimma, który w pocie czoła próbował nadać owej jednoznacznie erotycznej scenie pozory przyzwoitości. Najprościej byłoby, gdyby młody książę w ogóle nie pojawił się w sypialni królewny, ale z tej kluczowej sceny nie dało się przecież zrezygnować.

Als er aber herab fiel, war er kein Frosch, sondern ein Königssohn mit schönen und freundlichen Augen. Der war nun nach ihres Vaters Willen ihr lieber Geselle und Gemahl. Da erzählte er ihr, er wäre von einer bösen Hexe verwünscht worden, und Niemand hätte ihn aus dem Brunnen erlösen können als sie allein, und morgen wollten sie zusammen in sein Reich gehen. Dann schliefen sie ein, und am andern Morgen, als die Sonne sie aufweckte, kam ein Wagen heran gefahren... (Grimm 1857: 4) 
Gdy żaba upadła na podłogę, nie była już żabą, ale królewiczem o pięknych, przyjaznych oczach. I tak oto, zgodnie z wolą ojca, stał się on jej ukochanym towarzyszem i małżonkiem. Opowiedział jej, że został zaklęty przez złą wiedźmę i nikt oprócz królewny nie mógł wybawić go ze studni. Rano mieli udać się razem do jego królestwa. Potem zasnęli, a gdy zbudziło ich słońce, nadjechała kareta... (Grimm 2010, t. 1: 14)

W powyższym cytacie widać wyraźne ingerencje Wilhelma i łatwo się domyślić motywacji redaktora:

1) nie pojawia się fragment, w którym mowa, że książę wszedł „na łóżko",

2) „piękny, młody książę” staje się „królewiczem o pięknych, przyjaznych oczach",

3) pojawia się istotny wtręt, że wszystko dzieje się „zgodnie z wolą ojca”, a nie - jak w pierwszej wersji - zgodnie z obietnicą królewny,

4) książę stał się nie tylko towarzyszem, lecz również małżonkiem w ten sposób za sprawą odwołania do instytucji małżeństwa „moralnie naganna" sytuacja zostaje zalegalizowana,

5) zostaje dodana opowieść księcia, która odwraca uwagę od dwuznaczności, a rozbudowane zdanie redukuje dynamizm całej sceny,

6) zostaje dodana informacja, że królewna uda się z księciem (który w niewiadomy sposób stał się już jej małżonkiem) do jego królestwa,

7) i ostatnia istotna zmiana: młodzi ludzie nie tyle „zasnęli razem usatysfakcjonowani”, co po prostu „zasnęli”, a zdanie ma dalszy ciąg („...a gdy zbudziło ich słońce”), w wyniku czego czytelnik nie poświęca większej uwagi faktowi, że młodzi przebywali razem w jednym łóżku.

Wilhelm miał rzeczywiście niełatwe zadanie, by o tak jednoznacznej historii opowiedzieć w sposób oględny, i znać tutaj, że był naprawdę mistrzem pracy redakcyjnej. Z drugiej strony, jest to bardzo poglądowy przykład, jak ściśle zmiany treściowe pociągają za sobą zmiany stylistyczne. Tekst został oczywiście rozbudowany ( $z$ dwóch zdań otrzymujemy teraz pięć) i poszerzony o wyjaśniające dodatki, co nie tylko narusza prostotę baśni, lecz również linearność akcji i dynamizm tekstu. Owszem, ostatnie zdanie tego fragmentu z pierwszego wydania jest przesycone erotyką (choć po prawdzie - rozpoznawalną jedynie dla starszych odbiorców), ale równocześnie jest zdaniem dynamicznym i spójnym. Wersja $z$ wydania ostatniego jest w porównaniu do tego koturnowa i nieprzyjemnie gładka. Także więc i z takich czysto estetycznych powodów warto byłoby przybliżyć czytelnikowi polskiemu pierwsze, niewygładzone wersje baśni. 
Na marginesie: porównanie tego jednego krótkiego fragmentu z Żabiego króla, które ujawnia złożone zabiegi Wilhelma, powinno otwierać drogę do prześledzenia redakcyjnej pracy Grimmów w sposób bardziej kompleksowy. Tutaj otwiera się szerokie pole badawcze.

\section{0 konieczności przekładu wersji z roku 1812 na język polski}

Powyższe, zaledwie wstępne i fragmentaryczne porównanie obydwu wersji: z roku 1812 i 1857, jasno ukazuje, że w przypadku pierwszego wydania baśni braci Grimm mamy do czynienia z odmienną jakością - zbiorem baśni przeznaczonym dla innego odbiorcy i skompletowanym na podstawie szczególnych założeń wstępnych dotyczących formy i treści. Polscy badacze, którzy analizują baśnie Grimmów z różnych pozycji: literaturoznawczej, historycznej, pedagogicznej, folklorystycznej, antropologicznej itd., a opierają się przy tym nie na oryginale, lecz na przekładach, mają - jak to już zostało wspomniane - dostęp jedynie do ostatniej wersji: najbardziej wygładzonej i najbardziej odbiegającej do pierwowzoru. Tym samym nie mają wglądu w całość złożonego zjawiska, jakim jest zbiór Kinder- und Hausmärchen.

Chciałabym zebrać teraz w całość argumenty przemawiające za koniecznością polskiego przekładu pierwszego wydania baśni Grimmów. Myślę, że jest oczywiste, iż taka publikacja stałaby się ważnym materiałem dla wszystkich wspomnianych wyżej badaczy baśni (folklorystów, antropologów, polonistów). Już sama analiza porównawcza przekształceń, jakim podlegało pierwsze wydanie, może okazać się tak owocna, by zmienić postrzeganie baśni Grimmów w Polsce . Poza wymiarem czysto teoretycznym należy wskazać na praktyczne wykorzystanie "nieczyszczonych” baśni choćby w ramach bajkoterapii, a prężnie rozwijające się ostatnio grupy opowiadaczy baśni (jak na przykład poznańska grupa Baśnie Właśnie) mogłyby znacząco poszerzyć swój repertuar o nowe, oryginalne wersje znanych baśni i o baśnie nieznane.

${ }^{9}$ Przy tym nietrudno zauważyć, że większość młodych badaczy opiera się dzisiaj na źródłach anglojęzycznych, poznając Grimmów za pośrednictwem trzeciego języka. Warto, by badacze ci, jeśli nie znają niemieckiego, mieli dostęp do wiarygodnego źródła polskojęzycznego. 


\section{Jak tłumaczyć? Last, but not least}

Ostatnim pytaniem pośród uwag wstępnych, o ile uznamy, że istotnie warto przełożyć pierwszą edycję baśni Grimmów na język polski, jest pytanie praktyczne: ,jak tłumaczyć?”.

$\mathrm{Na}$ to pytanie spróbuję odpowiedzieć w pierwszej osobie. Jako tłumaczka „kanonicznej” wersji baśni z roku 1857, czyli Baśni dla dzieci i dla domu (2010), miałam ułatwione zadanie, ponieważ ostateczny tekst baśni został dopracowany przez Wilhelma Grimma na tyle starannie, że nieomal wystarczyło precyzyjnie podążać za tekstem. Jako tłumaczka przeciwna poprawianiu czy cenzurowaniu oryginału starałam się możliwie najdokładniej odwzorować zamiar stylistyczny i ideologiczny autorów, aczkolwiek jasne jest, że taka wierność ma swoje ograniczenia, o ile tekst przeznaczony jest dla szerokiej publiczności. Ponadto należy pamiętać, że proces wydawniczy nie jest podporządkowany jedynie decyzji tłumacza, bo i wydawnictwo może wydatnie wpłynąć na ostateczny kształt utworu.

W tej sytuacji pytanie: „jak tłumaczyć?” należy uzupełnić o pytanie: „dla kogo tłumaczyć?”. Bo jeśli tłumaczyć będziemy dla badaczy, to wierność w przekładzie musiałaby dotyczyć najdrobniejszych szczegółów, takich jak interpunkcja i formatowanie tekstu, a konkordancja terminologiczna byłaby tak samo istotna jak w przekładach Biblii. Mielibyśmy wówczas do czynienia z przekładem literalnym, przekładem przywiązanym do litery dzieła, co Antoine Berman opisuje następująco: „Pierwotniejsza niż odtwarzanie sensu jest praca nad literą, praca, dzięki której z jednej strony przekład odtwarza zespół znaczeń właściwy utworom (będący czymś więcej niż sens), z drugiej strony przekształca własny język" (Berman 2009: 264).

W takim przypadku praca redakcyjna, zmierzająca do uzyskania tekstu płynnego (Venuti), łatwego w lekturze, musiałaby zostać ograniczona do minimum. Równocześnie taki przekład musiałby zostać opatrzony szczegółowym wstępem i przypisami. Wydaje się, że w obliczu przedstawionych argumentów przemawiających za koniecznością przekładu pierwszej wersji baśni braci Grimm jedyną sensowną strategią przekładu byłaby dosłowność, bo właśnie taki kształt przekładu pozwalałby badaczom polskim analizować rozmaite aspekty baśni i porównywać je z wersją ostateczną.

Oczywiście dosłowność to pewien postulat, bo problemem pozostaje zakres tej dosłowności: mógłby to być choćby przekład interlinearny, posunięty aż do nasycenia tekstu docelowego neologizmami i kalkami językowymi. Wobec zbyt dosłownych przekładów często nasuwa się refleksja, że może po prostu łatwiej nauczyć się języka oryginału. Ponadto taka filologiczna wier- 
ność ma swoje ograniczenia: podstawowym dylematem w odniesieniu do wydania $\mathrm{z}$ roku 1812 będzie pytanie, jak przełożyć baśnie zapisane w całości $\mathrm{w}$ dialekcie.

Z kolei poszerzenie grona odbiorców baśni powoduje, że przekład musiałby być mniej chropowaty i bardziej dopracowany stylistycznie, gdyż filologiczna wierność i zachowywanie wszelkich filologicznych smaczków stanowi raczej przeszkodę w lekturze. I tutaj znowu pojawia się pytanie o zakres możliwych zmian, które mogą - w ostatecznym rozrachunku - przysłonić wszystkie te cechy, którymi wyróżnia się wydanie pierwsze.

Jako tłumaczka musiałabym zatem znaleźć roztropną drogę pośrednią między nieczytelnością przekładu interlinearnego a wersją poprawną stylistycznie. Najbardziej wskazana byłaby publikacja dwóch równoległych wersji przeznaczonych: dla badaczy i dla szerokiej publiczności, ale znając realia, wielkim sukcesem byłoby, jeśli ukazałby się chociaż jeden polski przekład pierwszego wydania baśni. Osobiście skłaniam się do następującego kompromisowego rozwiązania: powinien powstać krytyczny przekład całości oraz bardziej popularny przekład wybranych baśni (najlepiej owych 37 nieznanych).

\section{Literatura}

\section{Teksty źródłowe}

Grimm, J. i W., 1812, Kinder- und Hausmärchen, Berlin.

Grimm, J. i W., 1857, Kinder- und Hausmärchen, Göttingen.

Grimm, J. i W., 2010, Baśnie dla dzieci i dla domu, tłum. E. Pieciul-Karmińska, Poznań.

\section{Literatura sekundarna}

Berman, A., 2009, „Przekład jako doświadczenie obcego”, tłum. U. Hrehorowicz, [w:] Współczesne teorie przekładu, P. Bukowski, M. Heydel (red.), Kraków.

Ewers, H.-H., 2012, „»Sie nähren unmittelbar, wie der Honig, süß und sättigend, ohne irdische Schwere...« Vom unaufhaltsamen Aufstieg der Grimm'schen Märchenideals im Biedermeier", [w:] Das Wissenschaftsmagazin Forschung Frankfurt, Frankfurt a. Main, s. 38-43.

Kondratczyk, D., 2013, „Językowy obraz rodziny w baśniach braci Grimm”, [w:] Grimm: potegga dwóch braci. Kulturowe konteksty Kinder- und Hausmärchen, W. Kostecka, M. Skowera (red.), Warszawa, s. 77-88. 
Krawczyk, A., 2013, „Motyw wędrówki na przykładzie wybranych baśni braci Grimm", [w:] Grimm: potęga dwóch braci. Kulturowe konteksty Kinderund Hausmärchen, W. Kostecka, M. Skowera (red.), Warszawa, s. 89-100. Krysztofiak, M., 1999, Przekład literacki a translatologia, Poznań.

Martus, S., 2013, Die Brüder Grimm. Eine Biographie, Reinbek bei Hamburg. Rölleke, H., 2011, Die wahren Märchen der Brüder Grimm und wer sie ihnen erzählte, Frankfurt am Main.

Staniów, B., 2014, „Grimms' Fairy Tales in Poland. The analysis of publishing production in the years 1895-2011", [w:] Studia ad Bibliothecarum Scientiam Pertinentia XII, Kraków, s. 5-18.

Venuti, L., 1995, The Translator's Invisibility. A History of Translation, London-New York.

\section{On the necessity to translate the $1812 / 1815$ first edition of Children's and Household Tales by Brothers Grimm}

Summary

"Children's and Household Tales" by Brothers Grimm belong to the canon of world literature. Polish readers are familiar with the tales through the medium of translation but all existing Polish versions of the tales are based on the final version of the stories published in 1857. This was the $7^{\text {th }}$ edition of the tales issued 45 years after their first publication in the years $1812 / 1815$. It is interesting to know that both the first and the final edition of Brothers Grimm's "Children's and Household Tales" were aimed to reach different readers and vary from each other in different aspects concerning the style and content. Starting with the second edition (1819) the tales were rewritten, corrected and censored throughout the years. Wilhelm Grimm recreated the texts - originally intended for adult readers - into pure children's literature by adding Christian values and censoring erotic allusions. On the other hand, Wilhelm Grimm's editorial work was the main reason of the worldwide success of these German folk tales. Polish readers are not aware that they know only one, final and censored version of Grimm's Tales. It is also not common knowledge that there are 37 tales withdrawn from the first edition which are completely unknown to Polish readers. The article presents arguments for the necessity to translate the 1812/1815 first edition of "Children's and Household Tales"; additionally, an open question is posed how to translate the first edition into Polish: more literally for scholars or more dynamically for the wide readership.

Keywords: Grimm's Fairy Tales, translation of fairy tales

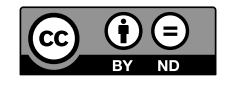

